\title{
Behind the Blackbox of Digital Business Models
}

\author{
Mashood Ahmad \\ University of Bamberg, Germany \\ mashood.ahmad@uni-bamberg.de \\ Tim Botzkowski \\ University of Bamberg, Germany \\ tim.botzkowski@uni-bamberg.de
}

\author{
Christoph Klötzer \\ University of Bamberg, Germany \\ christoph.kloetzer@uni-bamberg.de \\ Marcel Papert \\ University of Bamberg, Germany \\ marcel.papert@uni-bamberg.de
}

\begin{abstract}
In recent years global competition has undergone significant change as a result of the increasing digitalization or digital transformation of business and society. New forms of value creation have emerged, particularly through the emergence of companies such as Google and Facebook, and other digital disruptors. As a result of these developments, established companies face the challenge of aligning their business model with the new circumstances. One way of doing this is digitalization of the existing business model or designing a completely new digital business model. In this context, however, there is no commonly accepted definition and understanding of the nature of digital business models representing the context of Industry 4.0, cyber-physical systems, and the Internet of Things. So, this work is based on a literature review to help understand the concept of a digital business model. With this contribution, we enable scientific added value for business model research and at the same time help business practice to understand exactly what a digital business model is and which levers of transformation need to be considered.
\end{abstract}

Keywords: Business model, Digitalization, Smart products, Digital smart services, Digitized processes, Ecosystem, Platform, Data analytics

\section{Introduction}

Klaus Schwab, founder of the World Economic Forum, explained in his recent publication that all new developments and technologies have one key feature in common: "They leverage their pervasive power of digitalization and information technology" [61], which are enabled through the Fourth Industrial Revolution. In this context three clusters of megatrends are significant for the future of the economy and business regarding growth, employment, and the nature of work: physical megatrends (e.g. autonomous vehicles or 3D printing); biological megatrends (especially genetics); and digital megatrends (e.g. the Internet of Things (IoT)). In addition to the megatrends mentioned above, economic and social changes must always be considered.

Furthermore, Yoo et al. [82] explain that, as digital technologies become pervasive, these properties provide environments of open and flexible affordances that result in two unique characteristics of organizational innovation with digital technologies: convergence and generativity. These characteristics herald a new area of organizational scholarship exploring the digital materiality of new product and service designs, new business models and new organizational forms associated with pervasive digital technology. In particular, traditional industries and established companies have to deal with the new circumstances and create new (digital) business models to face future customer needs [68]. The world of digital business is complex, dynamic, and involves high levels of uncertainty and competition. Hence, in the more complex and sometimes unique digital business, the conventional business model needs to be transformed into a digital business model [3]. This work offers a conceptual approach to answering the following question: What is a digital business model?

A concrete explanation is necessary because, as a result of Internet-based platform businesses such as Google, Facebook, Amazon, Alibaba, and many others, the value creation across a broad range of markets and industrial sectors has changed and established companies have to understand how value creation can arise in the future [75]. Therefore, the challenges for established companies in the digital age are analyzed and business models in the context of information systems (IS) research are determined. This is followed by a literature review of the digital business model 
literature and the implications for business practice. The conclusion contains a conceptualization of digital business models and an outlook for future research.

\section{Challenges for established companies in the digital age}

The new digital technologies (such as blockchain, cloud computing, or the IoT) present both gamechanging opportunities and existential threats to established companies [30,62], as they have to be on the lookout for existing and upcoming disruptive technologies that impact, or even threaten, their existing business model. In this context digitalization has unleashed fundamental changes in almost all industries [71] and has emerged as a research priority in many academic disciplines, such as business research and IS research [42].

Indeed, Al-Debei et al. [2] explained in 2008 that, as a result of the upcoming digital era, the availability of appropriate levels of information and knowledge will become critical to the success of businesses, and organizations must adapt in order to survive and succeed as their business domains, processes, and technologies change in a world of increasing environmental complexity. Moreover, Bharadwaj et al. [13] pointed out that during the last decade impressive improvements in information, communication, and connectivity technologies have unleashed new functionalities. Thus, the "post-dotcom" decade has seen firms - both established and start-ups - taking advantage of lowering price-to-performance levels of computing (hardware and software), as well as global connectivity through standard protocols (e.g. Internet and mobile web) to adapt their business infrastructure to the new digital era. "Our era is one of increasingly pervasive digital technologies, which penetrate deeply into the very core of the products, services, and operations of many organizations and radically change the nature of product and service innovations" [82].

Nevertheless, it should be mentioned that even companies in the primarily physical industries will not start their digital transformation journey from scratch. Instead, most companies are already finding ways to use digital information by providing interactive websites, improved customer service, or enhanced customer experiences $[10,11]$.

Based on the previous explanations, the question remains: What is a digital business model?

This question is extremely important, because in recent years "born digital" pioneers have grown into powerful behemoths (see, for example, Amazon, Facebook, and Google), while companies that had long dominated their industries have found their traditional value propositions under threat [62]. Airbnb, Uber, or Netflix are also examples of fast-growing start-ups, which position themselves with digital business models, meaning business models with minimal physical components [29], and take market shares from companies with traditional business models [18]. By the integration and exploitation of new technologies, established firms can implement major business improvements in order to remain competitive and foster new growth potential [66]. The integration and exploitation of these technologies have become a crucial success factor and will lead to the disruption of whole business models as a result of structural and organizational challenges [34]. Because of the disruptive character of digitalization, established firms must rethink their business models to remain competitive in the future, or implement new digital business models [71] in order to develop different value propositions and revenue-sharing models [25].

\section{Business models and IS research}

Every company uses a specific combination of assets and this utilization leads to the capabilities to build a business model that is unique to its goals. Capabilities, in this sense, can be understood as meta-competencies that go beyond operational competence [67]. In a fastchanging environment these capabilities will make the difference between innovation leaders and the competitive advantage of business models. The business model determines whether a company destroys or creates value in a specific way. Or, to revisit our analogy, business models ultimately determine whether a company succeeds in cracking the value code [16]. This means, first, that "business model" is a term that is often used to describe the key components of a business [32], and, second, that in business practice every company has a business model, whether this is articulated or not $[17,26]$.

Even though the origin of the concept has its foundations in economic practice $[28,41]$, the term business model has already been present in scientific discussions for more than fifty years. There is still a high number of publications being published dealing with the business model topic. Not only practitioners, but also scientific researchers from various fields such as information management, strategy, and organization theory, are participating in the scientific discourse $[60$, $79,84]$. Despite the long-lasting practical and academic discussion, no commonly accepted definition and understanding of the nature of business models have been established [84]. Several different definitions can be found in the scientific literature. Some examples are: 
- "A business model depicts the content, structure, and governance of transactions designed so as to create value through the exploitation of business opportunities." [4]

- "We define a business model as a representation of a firm's underlying core logic and strategic choices for creating and capturing value within a value network." [63]

- "A business model articulates the logic and provides data and other evidence that demonstrates how a business creates and delivers value to customers. It also outlines the architecture of revenues, costs, and profits associated with the business enterprise delivering that value." [68]

The diversity in the available definitions leads to confusion in the terminology [46]. For us, "A business model describes the rationale of how an organization creates, delivers, and captures value" [47], and it is not just a strategy [44, 63]. Moreover, Teece [68] pointed out: "A business model is more generic than a business strategy. Coupling strategy and business model analysis is needed to protect competitive advantage resulting from new business model design." Because business models are fundamentally linked with technological innovation [6], the topic is very relevant for the information systems/business and information systems engineering (IS/BISE) community, and several research streams can be identified [71].

The first stream deals with the impact of new technologies such as electronic data interchange (EDI) on the division of labor between companies and therefore represents important aspects of the outside perspective on a business model. In addition, the business models of intermediaries were discussed at the time. The second stream deals with a whole new way of value creation and capturing that has been enabled through digital business models. The third stream looks at the specific role of information and communication technology (ICT) and how it has changed to being the driver of a new wave of industrialization, namely, Industry 4.0, from being simply a cost factor in businesses. The fourth stream looks at ICT-enabled changes in product and service models, especially in retail and the media. And, last but not least, the emergence of entirely new business models is looked at in the research community.

All of these research streams are still in the spotlight of the IS/BISE community and are being differentiated from one another with great speed, which can be seen by the sheer number of publications dealing with related topics. With respect to our statements in Chapter 1, we focus on research belonging to the fifth stream of business model research in IS/BISE, where we contribute to the research stream. It is very important to understand that without a proper, theory-based conceptualization and formalization, however, adequate IT support for developing and managing business models can hardly be provided $[68,71]$. Here, we can still learn a lot about digital business models, combining the opportunities arising from ICT, which is the digital enabler, and putting them together with theoretical perspectives, that is, IS/BISE research.

\section{Literature review}

First, it is essential to understand the literature in the addressed field before it is possible to perform meaningful research [15]. A systematic literature review therefore demonstrates an author's knowledge of a particular field of study [53]. In order to reduce bias during the literature review, the following steps were taken [21]: (4.1) problem formulation; (4.2) locating articles; (4.3) article selection and evaluation; (4.4) analysis and synthesis of articles; and (4.5) review of the results. A detailed report of the search strategy ensured that the search could be replicated [21]. The chosen approach was largely congruent with other highly structured approaches, even though the naming of, and delimitation between, the individual steps might vary. Having synthesized and analyzed the literature, we describe the basis and target of the digital business model (4.6).

\subsection{Problem formulation}

As stated in the introduction, small and mediumsized enterprises, and large-scale enterprises, must take on the challenge of transforming their traditional business models into digital business models. However, it is not at all clear what is meant by a digital business model. Following this, a basic specification is necessary, since a clear understanding of the concept is the basic prerequisite for formulating a digital strategy [33]. The fundamental problem, and the central research question, is: What is a digital business model?

\subsection{Locating articles}

For the literature search, the Databases Business Source Ultimate, the SSCI-Database, and the Association for Information Systems Electronic Library were selected, as they have a large repository of business research, as well as information systems research, and they are typically used in literature reviews, for example, [23, 84]. After selecting the databases, the keywords were defined. Indeed, Denyer and Tranfield [21] explain that keywords are built from the scoping study, the literature, and discussions within 
the research team. Following these steps, the complete search string was constructed as follows: ("digital" OR "IIoT" OR "Industrial Internet of Things" OR "IoT" OR "Internet of Things" OR "Industry 4.0" OR "smart product*" OR "smart service*") AND ("business model" OR "business idea" OR "business concept" OR "revenue model" OR "economic model") AND ("elements" OR "dimensions").

As is common in systematic reviews, the authors performed a search in the title, abstract, and keywords.

We searched for articles published in the English language and within academic journals, as well as in conference proceedings [21]. The time horizon for locating articles was between 1999, starting with the first use of the phrase "Internet of Things" by Ashton [5], and February 1st, 2019. The electronic search process resulted in the identification of 215 articles from academic journals and conference proceedings. After removing duplicates from the sample [54], 126 articles remained.

\subsection{Article selection and evaluation}

In the next step, we had to determine which articles would be included and which excluded from the review. As already stated, the specific criteria are influenced by the review's focus, goals, and coverage [53]. First, in line with Klötzer and Pflaum [38], the abstract of each paper was examined by all four researchers in order to eliminate papers that were not directly related to the problem formulation. Relevant articles had to deal with digital business models in a non-trivial and nonmarginal way [84]. Following this process, 37 articles remained.

\subsection{Analysis and synthesis of articles}

After assembling the collection of relevant articles by examining the abstracts, the analysis and synthesis commenced [21]. In this context, a sharper focus was placed on papers offering a specific definition or explanation of the nature of digital business models. To realize this, the articles were analyzed in their entirety by the researchers (i.e. full-paper analysis). Initially, we started analyzing the articles for a specific definition of a digital business model. We were able to identify only two publications that attempted to deliver a precise definition of a digital business model:

- 'A 'digital business model' can thus be defined as a business model whose underlying business logic deliberately acknowledges the characteristics of digitization and takes advantage of them; both in interaction with customers and business partners, and in its internal operations." [7]
- "A business model is digital if changes in digital technologies trigger fundamental changes in the way business is carried out and revenues are generated." [71]

Moreover, based on the literature review by Bock and Wiener [14], digital business models are described as "business models for [products and] services provided through digital platforms" by El Sawy and Pereira [24], as well as how businesses engage with their customers digitally to create value, via digitals channels [77]. However, Bock and Wiener [14] do not reveal exact keywords and other relevant search settings in their literature review; therefore, their results cannot be replicated. Still, the definitions they provide must be considered.

As a result of the low number of indications and the vague definitions identified, we further analyzed the articles according to characteristic features. By reading the articles the researchers searched for characteristic elements of the digital business models used by the various authors. In order to gain insights into the specific characteristics of digital business models, a matrix analysis following the approach of Salipante et al. [57] - in the adaption of Webster and Watson [76] was conducted. According to Klötzer and Pflaum [38], a concept matrix can be created, which usually results in two different dimensions, with several sub-dimensions possible. One dimension could be associated with the identified relevant papers and the other could show the findings themselves. Because of the high number of relevant articles, the authors decided to present them in a column. The results of these assembling and synthesizing processes are shown in Table 1.

At the end of the synthesizing processes, we identified 20 articles dealing with digital business models in a non-trivial and non-marginal way. The analysis of the paper was based on a deductive and criteria sliding logic. The research team looked for specific elements in order to find out in which combination these elements appeared in the papers analyzed. Then these elements were discussed in two rounds and reassigned to distinguishable elements. Therefore, the elements are said to be part of a digital business model. Within that literature, we found six major elements describing a digital business model: smart products, digital smart services, digitized processes, ecosystem, platform, and data analytics. In the next chapter, we will discuss these elements, followed by the basis and target of a digital business model. 


\subsection{Review and discussion}

Based on the findings (see Table 1), the identified elements of a digital business model are discussed separately in the following chapters.

Table 1. Elements of a digital business model - a concept matrix

\begin{tabular}{|c|c|c|c|c|c|c|}
\hline & 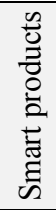 & 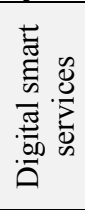 & 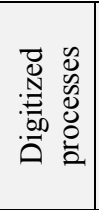 & 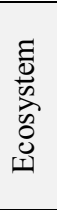 & $\begin{array}{l}\text { E्ञ } \\
\stackrel{0}{\frac{\pi}{2}} \\
\frac{\pi}{2}\end{array}$ & 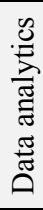 \\
\hline $\begin{array}{c}\text { Baerenfaenger } \\
\& \text { Otto }(2015) \\
{[7]}\end{array}$ & & & $X$ & $X$ & & $\mathrm{X}$ \\
\hline $\begin{array}{l}\text { Berman } \\
(2012)[11]\end{array}$ & $X$ & $X$ & $X$ & $X$ & & $\mathrm{X}$ \\
\hline $\begin{array}{c}\text { Bock \& } \\
\text { Wiener (2017) } \\
{[14]}\end{array}$ & $X$ & $X$ & & $X$ & $X$ & $\mathrm{X}$ \\
\hline $\begin{array}{l}\text { Dellermann et } \\
\text { al. (2017) [20] }\end{array}$ & & & & $X$ & & \\
\hline $\begin{array}{c}\text { Hamidi \& } \\
\text { Jahanshahifard } \\
\text { (2018) [31] }\end{array}$ & $X$ & $X$ & & & & $X$ \\
\hline $\begin{array}{c}\text { Keen \& } \\
\text { Williams } \\
(2013)[36]\end{array}$ & $X$ & & & $X$ & $X$ & \\
\hline $\begin{array}{l}\text { Kiel et al. } \\
(2017)[37]\end{array}$ & $X$ & $X$ & & $X$ & $X$ & $X$ \\
\hline $\begin{array}{c}\text { Loebbecke \& } \\
\text { Picot (2015) } \\
{[43]}\end{array}$ & & & $\mathrm{X}$ & $X$ & & $\mathrm{X}$ \\
\hline $\begin{array}{c}\text { Paulus- } \\
\text { Rohmer et al. } \\
\text { (2016) [49] }\end{array}$ & & $X$ & & $X$ & $X$ & \\
\hline $\begin{array}{l}\text { Qin \& Yu } \\
(2014)[52]\end{array}$ & & & & & $X$ & \\
\hline $\begin{array}{c}\text { Remane et al. } \\
(2017)[55]\end{array}$ & $X$ & X & X & $X$ & $X$ & \\
\hline $\begin{array}{l}\text { Richter et al. } \\
\text { (2017) [56] }\end{array}$ & & & & & $X$ & \\
\hline $\begin{array}{c}\text { Schallmo et al. } \\
\text { (2017) [59] }\end{array}$ & & & & $X$ & & $X$ \\
\hline $\begin{array}{c}\text { Teece \& } \\
\text { Linden (2017) } \\
{[69]}\end{array}$ & $X$ & $X$ & $X$ & $X$ & & \\
\hline $\begin{array}{c}\text { Terrenghi \& } \\
\text { Schwarz } \\
(2018) \text { [70] }\end{array}$ & $X$ & $X$ & & & $X$ & $X$ \\
\hline $\begin{array}{c}\text { Wåge \& } \\
\text { Crawford } \\
(2017) \text { [73] } \\
\end{array}$ & & & & $\mathrm{X}$ & & \\
\hline $\begin{array}{l}\text { Wall et al. } \\
\text { (2007) [74] }\end{array}$ & $X$ & & & & $X$ & \\
\hline
\end{tabular}

\begin{tabular}{|c|c|c|c|c|c|c|}
\hline & 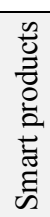 & 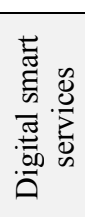 & 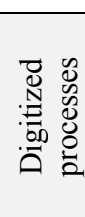 & 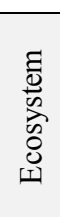 & 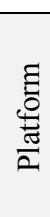 & 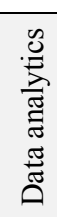 \\
\hline $\begin{array}{c}\text { Weill \& } \\
\text { Woerner } \\
(2018)[78]\end{array}$ & $X$ & & & $X$ & $X$ & $X$ \\
\hline $\begin{array}{c}\text { Wnuk \& } \\
\text { Murari (2016) } \\
{[80]}\end{array}$ & & & & & $X$ & \\
\hline $\begin{array}{c}\text { Zott \& Amit } \\
\text { (2017) [85] }\end{array}$ & $X$ & & & & $X$ & \\
\hline $\begin{array}{l}\text { Number of } \\
\text { Indications } \\
\end{array}$ & 11 & 8 & 5 & 13 & 12 & 9 \\
\hline
\end{tabular}

4.5.1. Smart products. It is explained by Teece and Linden [69] that smart products, and the services built upon them, can create new business models. Nowadays, simply selling physical products might not be enough in the digital era. The shift of value from physical artefacts to "smart" products, and the data they are creating, represents a new way to create value [39]. Such smart and connected products offer exponentially expanding opportunities for new functions, greater reliability and product utilization, as well as capabilities that cut across and transcend traditional product boundaries [51]. This change forces business to rethink and reorganize nearly everything they do internally [51], and also leads to blurred industry boundaries [1], which creates a complete new environment for businesses, where they have to find a new identity for themselves. The digitalization of products and complementary services can enable or require different forms of company monetization, or even adjustments to companies' business scope, if other markets or new customer segments are addressed [33]. The target is to create valuable new smart products and complementary services that customers are willing to pay for [50]. However, digital technology's transformative impact on industrial-age products has remained surprisingly unnoticed in the IS literature so far [81].

4.5.2. Digital smart services. Following Remane et al. [55], a digital business model differs from traditional business models because of the possibility of offering digital services, either with a complementary (smart) product or without, as a "pure" service, which can be reproduced for practically zero marginal cost. Companies can, for example, offer digital financial services, where new revenue-based services can be offered online and through mobile devices [11]. At the center of digital services, value can only be created through a collaborative process designed with the customer [14]. Furthermore, Klötzer and Pflaum [39] 
have shown that an essential element of digital transformation, especially for traditional productoriented companies, are digitized services and orientation toward a service-oriented company. In that case, digital or smart services are based on smart products [12]. The offering of digital services is primarily based on data and can fit with the overall corporate strategy [49]. "Ultimately, any privately offered digital service must pay its own way, directly or indirectly, by capturing a share of the value it creates if it is to be a sustainable business" [69]. As a result of the importance of services, companies have, across the business landscape, embraced service as an engine of their firms' growth [9].

4.5.3. Digitized processes. As Loebbecke and Picot [43] explain, the creation and establishment of new digital business models are based, among other things, on digitalization, and the aim is to optimize and automate existing processes to increase the overall efficiency and quality of products and services. Especially for manufacturing companies, cyberphysical systems (CPS) are of particular relevance in this context [49]. Increasing digitization of business processes dramatically reduces transaction costs for collecting information, communication, and controlling activities. The digitization of business processes denotes the transition from conducting business activities in a traditional manner to conducting them in a digital form [8]. The reach of the digitized processes, regarding the extent to which a firm creates common, integrated, and connected IT-enabled processes, and the richness of digitized processes, focus on the quality of information collected in the process [58].

4.5.4. Ecosystem. It is important to understand that digitalization brings companies closer together. Accordingly, the nature and strength of interactions between those companies gain significant importance [49]. A digital ecosystem can be defined as an infrastructure enabling cooperation, knowledge sharing, and a digital business ecosystem, supported by ICT [19]. Therefore, it can be stated that a digital ecosystem is the economic version of an ecosystem found in nature. By forming ecosystems, established companies can compete with an expanding range of digital disrupters. This can be realized by building strong and complementary partnerships among different ecosystem players (i.e. business and IT) to design new business models, bridging gaps between previously separated business units and ecosystem players. Manufacturers that have not yet advanced their digital transformation, or which lack the internal resources to do so, must rely on external partner networks and development partners, who possess the know-how or the necessary resources
[37]. Goals can be to create new digital value, to improve information flows and exchange between business ecosystem partners, and to enable a seamless customer experience. Further goals are achieved using scale or scope effects regarding the convergence of physical infrastructures (e.g. transportation), digital infrastructures (e.g. connectivity), and the identification of new cross-industry structures [50]. Companies in an ecosystem include not just customers and suppliers but also producers of complementary products and services, logistics providers, outsourcers, financiers, and so on $[45,48]$.

4.5.5. Platform. A platform is the central element of ensuring communication and connectivity, displaying its full potential when combined with an ecosystem [27, 35]. Then, the platform constitutes the foundation of ecosystem collaboration, is provided by a keystone actor, and delivers basic functionalities for products and services, and their implementation. A product or service is thereby ultimately realized by the partners within the ecosystem. Indeed, Remane et al. [55] point out that digital business models rely on platforms. The pursuit of a digital business model requires a robust and flexible enterprise platform, on which smart products and digital (smart) services can be readily delivered [64]. This could be a shared digital platform (a platform supporting simultaneous use by multiple companies, each of which can independently customize business processes for its own ecosystem) or a business community platform (tailored to the processes of a business community and used in substantially the same way by most community members, including competing orchestrators) [45]. Even though the concept of a platform itself is nothing fundamentally new, its relevance for the successful implementation of a digital business model is outstanding. Linked to this is the observation that software components gain significantly in importance since they are designed to ensure a direct customer interface and access [40].

4.5.6. Data analytics. The ability to identify correlations and patterns in various types of data, and also to extract insights relevant to the value proposition model of the business, is a key element of digital business models, as proposed by Bock and Wiener [14]. For example, companies in the process of digital transformation can use data analysis methods as an enabler of transformation to improve their predictions [59]. Companies already advancing within a digital business model can complement or substitute managerial decision-making with big data analytics [43]. Berman argues that data analytics is an essential capability to respond to "fast-changing customer requirements" [11], which is often imperative for 
companies in order to withstand disruptions to their business model and remain competitive by serving new customer demand and establishing new forms of customer engagement [43].

\subsection{Target and basis of a digital business model}

Companies are rethinking how they will create customer added value and efficiency benefits in the digital economy, and they are investing in new technologies and new capabilities to reposition themselves as digital leaders $[1,62]$.

The primary target of a digital business model is the customer focus. In this context a deep focus on appropriate value propositions is necessary to achieve an improved customer experience [11]. Customers can therefore be involved in the product-manufacturing process, which provides considerable added value [49].

The new dynamic capabilities form the basis of smart products and digital (smart) services [65], and they are relevant for digital business strategy [7]. Creating a new digital business model should be done in interaction with customers, business partners, and with the organization's internal operations to achieve interactivity [11] and to capture (technological) developments and evolving needs. To build such capabilities, a one-time initiative is not sufficient because a full organizational approach to align the related structure, processes, technology, and people is required [64]. Business managers have to understand and augment the full range of their organization's capabilities if they design and implement digital business models that track the evolution of technology and consumer demand. These capabilities are embedded in both organizational routines and managerial cognition [69].

\section{Extraction of information from the literature review and conceptualization of a digital business model}

As a result of the fact that the idea of digital business models goes far beyond the traditional and conventional understanding of business models, the topic has become highly relevant to IS and BISE researchers [72]. Based on the assumption that a business model describes how a company creates, delivers, and captures customer value (e.g. $[17,47])$, we subsume under the terminology "digital business model" the following components:

- The shift of value away from physical artefacts to smart products, enabling new business models through the utilization of data generated by these products;
- the offering of (pure) digital (smart) services, enabling scalable business models;

- the digitization of (internal) processes, enabling an increase in overall efficiency and quality and a reduction in transaction costs;

- the operation within an ecosystem, enabling strong and complementary partnerships between all possible participating actors;

- the accessibility of a platform for collaboration, enabling basic functionalities for (smart) products and services, and their implementation; and

- the capability to collect data and extract insights from it in order to use these insights to aid digital transformation, add value to the digital business model, and adjust to customer needs.

Even though not all of the analyzed papers contained each of the identified components, either they could be extracted from the individual context or its necessity resulted from the synthesis of the analyzed paper as a whole.

\section{Conclusion and future research}

Following the e-business model hype of the late 1990s, "digital business" appears to be the hype in terms of digitalization in the 2000s [7]. Digitalization means the touted accelerating transformation of business models [7]. In this context, we recommend the use of our conceptual definition as follows:

A digital business model is the mixed utilization of smart products and digital smart services, the digitization of internal processes, the operation within an ecosystem, the accessibility of a platform, as well as the utilization of data analytics.

There is sufficient evidence in today's economy that the digitalization trend raises more profound implications than just the introduction of a new distribution channel that the e-commerce development created. In fact, digitalization impacts entire business models; it not only questions incumbent ways of doing business but also offers opportunities for new start-ups [7]. The pace of technological progress and business innovation seems to have accelerated in recent decades, with the result that sustainably profitable business models are harder than ever to craft [69]. This could be a reason why many companies, such as Blackberry or BenQ, or Nokia, failed. These firms did not do anything wrong; they just kept doing what used to be the right strategy for too long and fell victim to the rigidity of their conventional business model. As a result of discontinuities, disruptions, convergence, and intense 
global competition, established companies world-wide need to transform their business models more frequently, and with more reach than in the past [22]. Managers need to design their future digital business model in order to make it competitive for the future [83]. Future research should focus on what a digital business model means in practice, and why these are changing. This implies that, in order to realize a digital business model, a company has to build, train, and preserve the necessary capabilities for the aforementioned components. For example, there is a need to understand which elements have greater influence on the development of a digital business model. The number of indications shows that there could be differences in the elements. Additionally, it could be investigated whether mixtures, and what combinations of the elements, lead to a more valuable digital business model. Finally, the authors also recommend a comprehensive theoretical discussion of our conceptional definition with classical theories. In particular, dynamic capabilities represent a promising theoretical lens for discussing our definition and elaborating the theoretical implications.

\section{References}

[1] M. Ahmad, M. Papert, and A. Pflaum, "Dynamic Capabilities related Implementation Skills for Internet of Things Solutions in the Digital Economy", Proceedings of the 51st Hawaii International Conference on System Sciences (HICSS), 2018, pp. 3996-4005.

[2] M.M. Al-Debei, R. El-Haddadeh, and D. Avison, "Defining the Business Model in the New World of Digital Business", Proceedings of the 14th Americas Conference on Information Systems (AMCIS).

[3] M.M. Al-Debei and D. Avison, "Developing a unified framework of the business model concept", European Journal of Information Systems, 19(3), 2010, pp. 359-376.

[4] R. Amit and C. Zott, "Value Creation in E-business", Strategic Management Journal, 22(6-7), 2001, pp. 493-520.

[5] K. Ashton, "That 'Internet of Things' Thing", RFID Journal, 22(7), 2009, pp. 97-114.

[6] C. Baden-Fuller and S. Haefliger, "Business Models and Technological Innovation", Long Range Planning, 46(6), 2013, pp. 419-426.

[7] R. Baerenfaenger and B. Otto, "Proposing a Capability Perspective on Digital Business Models", Proceedings of the 17th IEEE Conference on Business Informatics (CBI), 2015, pp. 17-25.

[8] A. BarNir, J.M. Gallaugher, and P. Auger, "Business Process Digitization, Strategy, and the Impact of Firm Age and Size: The Case of the Magazine Publishing Industry", Journal of Business Venturing, 18(6), 2003, pp. 789-814.
[9] M. Barrett, E. Davidson, J. Prabhu, and S.L. Vargo, "Service Innovation in the Digital Age: Key Contribution and Future Directions", MIS Quarterly, 39(1), 2015, pp. 135-154.

[10] S.J. Berman and R. Bell, "Digital Transformation: Creating New Business Models Where Digital Meets Physical", IBM Institute for Business Value, 2011, pp. 1-17.

[11] S.J. Berman, "Digital Transformation: Opportunities to Create New Business Models", Strategy \& Leadership, 40(2), 2012, pp. 16-24.

[12] D. Beverungen, O. Müller, M. Matzner, J. Mendling, and J. Vom Brocke, "Conceptualizing Smart Service Systems", Electronic Markets, 83(10), 2017, pp. 1-12.

[13] A. Bharadwaj, O.A. El Sawy, P.A. Pavlou, and N.V. Venkatraman, "Digital Business Strategy: Toward a Next Generation of Insights", MIS Quarterly, 37(2), 2013, pp. 471482

[14] M. Bock and M. Wiener, "Towards a Taxonomy of Digital Business Models - Conceptual Dimensions and Empirical Illustrations", Proceedings of the 38th International Conference on Information Systems (ICIS), 2017, pp. 1-19.

[15] D.N. Boote and P. Beile, "Scholars Before Researchers: On the Centrality of the Dissertation Literature Review in Research Preparation", Educational Researcher, 34(6), 2005, pp. 3-15.

[16] R.E.S. Boulton, B.D. Libert, and S.M. Samek, "A Business Model for the New Economy", Journal of Business Strategy, 21(4), 2000, pp. 29-35.

[17] H. Chesbrough, "Business Model Innovation: It's Not Just About Technology Anymore", Strategy \& Leadership, 35(6), 2007, pp. 12-17.

[18] C.M. Christensen and M. Overdorf, "Meeting the Challenge of Disruptive Change", Harvard Business Review, 78(2), 2000, pp. 66-77.

[19] A. Corallo, G. Passiante, and A. Prencipe, The Digital Business Ecosystem, Edward Elgar Publishing Ltd., Cheltenham, UK, 2007.

[20] D. Dellermann, A. Fliaster, and M. Kolloch, "Innovation Risk in Digital Business Models: the German Energy Sector", Journal of Business Strategy, 38(5), 2017, pp. 35-43.

[21] D. Denyer and D. Tranfield, "Producing a Systematic Review", in The Sage Handbook of Organizational Research Methods, D.A. Buchanan and A. Bryman, Editors. 2009. Sage Publications Ltd: Thousand Oaks, CA, USA.

[22] Y.L. Doz and M. Kosonen, "Embedding Strategic Agility", Long Range Planning, 43(2-3), 2010, pp. 370-382.

[23] C.F. Durach, A. Wieland, and J.A.D. Machuca, "Antecedents and Dimensions of Supply Chain Robustness: A Systematic Literature Review", International Journal of Physical Distribution \& Logistics Management, 45(1/2), 2015, pp. 118-137.

[24] O.A. El Sawy and F. Pereira, Business Modelling in the Dynamic Digital Space, Springer Berlin Heidelberg, Berlin, Heidelberg, 2013. 
[25] O.A. El Sawy, P. Kræmmergaard, H. Amsinck, and A.L. Vinther, "How LEGO Built the Foundations and Enterprise Capabilities for Digital Leadership", MIS Quarterly Executive, 15(2), 2016, pp. 141-166.

[26] A. Gambardella and A.M. McGahan, "Business-Model Innovation: General Purpose Technologies and their Implications for Industry Structure", Long Range Planning, 43(2-3), 2010, pp. 262-271.

[27] A. Gawer and M.A. Cusumano, Platform leadership: How Intel, Microsoft, and Cisco Drive Industry Innovation, Harvard Business School Press, Boston, MA, USA, 2002.

[28] G. George and A.J. Bock, "The Business Model in Practice and its Implications for Entrepreneurship Research", Entrepreneurship Theory and Practice, 35(1), 2011, pp. 83111.

[29] I. Haffke, B. Kalgovas, and A. Benlian, "The Role of the $\mathrm{CIO}$ and the $\mathrm{CDO}$ in an Organization's Digital Transformation", Proceedings of the 37th International Conference on Information Systems (ICIS), 2016, pp. 1-20.

[30] I. Haffke, B. Kalgovas, and A. Benlian, "The Transformative Role of Bimodal IT in an Era of Digital Business", Proceedings of the 50th Hawaii International Conference on System Sciences (HICSS), 2017, pp. 5460 5469.

[31] H. Hamidi and M. Jahanshahifard, "The Role of the Internet of Things in the Improvement and Expansion of Business", Journal of Organizational and End User Computing, 30(3), 2018, pp. 24-44.

[32] J. Hedman and T. Kalling, "The Business Model Concept: Theoretical Underpinnings and Empirical Illustrations", European Journal of Information Systems, 12(1), 2017, pp. 49-59.

[33] T. Hess, C. Matt, A. Benlian, and F. Wiesböck, "Options for Formulating a Digital Transformation Strategy", MIS Quarterly Executive, 15(2), 2016, pp. 123-139.

[34] A. Horlacher and T. Hess, "What Does a Chief Digital Officer Do? Managerial Tasks and Roles of a New C-Level Position in the Context of Digital Transformation", Proceedings of the 49th Hawaii International Conference on System Sciences (HICSS), pp. 5126-5135.

[35] M. Iansiti and R. Levien, The Keystone Advantage: What the New Dynamics of Business Ecosystems Mean for Strategy, Innovation, and Sustainability, Harvard Business School Press, Boston, MA, USA, 2004.

[36] P. Keen and R. Williams, "Value Architectures for Digital Business: Beyond the Business Model", MIS Quarterly, 37(2), 2013, pp. 643-648.

[37] D. Kiel, C. Arnold, and K.-I. Voigt, "The influence of the Industrial Internet of Things on business models of established manufacturing companies - A business level perspective", Technovation, 68, 2017, pp. 4-19.

[38] C. Klötzer and A. Pflaum, "Cyber-Physical Systems (CPS) in Supply Chain Management: A Definitional
Approach", Proceedings of the 27th Conference of the Nordic Logistic Research Network (NOFOMA), 2015, pp. 190-205.

[39] C. Klötzer and A. Pflaum, "Toward the Development of a Maturity Model for Digitalization within the Manufacturing Industry's Supply Chain", Proceedings of the 50th Hawaii International Conference on System Sciences (HICSS), 2017.

[40] C. Klötzer, "Bridging two worlds: How Cyber-Physical Systems advance Supply Chain Management", in Mobility in a Globalised World 2018, E. Sucky, R. Kolke, N. Biethahn, J. Werner, and M. Vogelsang, Editors. 2019. University of Bamberg Press: Bamberg.

[41] X. Lecocq, B. Demil, and J. Ventura, "Business Models as a Research Program in Strategic Management: An Appraisal based on Lakatos", M@n@gement, 13(4), 2010, pp. 214-225.

[42] A. Leischnig, S. Wölfl, and B. Ivens, "When Does Digital Business Strategy Matter to Market Performance?", Proceedings of the 37th International Conference on Information Systems (ICIS), 2016, pp. 1-16.

[43] C. Loebbecke and A. Picot, "Reflections on Societal and Business Model Transformation Arising from Digitization and Big Data Analytics: A Research Agenda", The Journal of Strategic Information Systems, 24(3), 2015, pp. 149-157.

[44] J. Magretta, "Why Business Models Matter", Harvard Business Review, 80(5), 2002, pp. 86-92.

[45] M.L. Markus and C. Loebbecke, "Commoditized Digital Processes and Business Community Platforms: New Opportunities and Challenges for Digital Business Strategies", MIS Quarterly, 37(2), 2013, pp. 649-654.

[46] M. Morris, M. Schindehutte, and J. Allen, "The Entrepreneur's Business Model: Toward a Unified Perspective", Journal of Business Research, 58(6), 2005, pp. 726-735.

[47] A. Osterwalder and Y. Pigneur, Business Model Generation: A Handbook for Visionaries, Game Changers, and Challengers, Wiley, Hoboken, NJ, USA, 2010.

[48] M. Papert and A. Pflaum, "Development of an Ecosystem Model for the Realization of Internet of Things (IoT) Services in Supply Chain Management", Electronic Markets, 27(2), 2017, pp. 175-189.

[49] D. Paulus-Rohmer, H. Schatton, and T. Bauernhansl, "Ecosystems, Strategy and Business Models in the age of Digitization - How the Manufacturing Industry is Going to Change its Logic", Proceedings of the 49th CIRP Conference on Manufacturing Systems (CIRP-CMS), 2016, pp. 8-13.

[50] E. Piccinini, A. Hanelt, R. Gregory, and L.M. Kolbe, "Transforming Industrial Business: The Impact of Digital Transformation on Automotive Organizations", Proceedings of the 36th International Conference on Information Systems (ICIS), 2015, pp. 1-20.

[51] M.E. Porter and J.E. Heppelmann, "How Smart, Connected Products are Transforming Competition", Harvard Business Review, 92(11), 2014, pp. 64-88. 
[52] Qin Qiuli and Yu Hao, "Research on the Internet of Things Business Model of Telecom Operators Based on the Value Net", in Proceedings of International Symposium Management, Innovation \& Development (MID). 2014.

[53] J.J. Randolph, "A Guide to Writing the Dissertation Literature Review", Practical Assessment, Research \& Evaluation, 14(13), 2009, pp. 1-13.

[54] L. Rashman, E. Withers, and J. Hartley, "Organizational Learning and Knowledge in Public Service Organizations: A Systematic Review of the Literature", International Journal of Management Reviews, 11(4), 2009, pp. 463-494.

[55] G. Remane, A. Hanelt, R.C. Nickerson, and L.M. Kolbe, "Discovering Digital Business Models in Traditional Industries", Journal of Business Strategy, 38(2), 2017, pp. 4151 .

[56] C. Richter, S. Kraus, A. Brem, S. Durst, and C. Giselbrecht, "Digital Entrepreneurship: Innovative Business Models for the Sharing Economy", Creativity and Innovation Management, 26(3), 2017, pp. 300-310.

[57] P. Salipante, W. Notz, and J. Bigelow, "A Matrix Approach to Literature Reviews", Research in Organizational Behavior: An Annual Series of Analytical Essays and Critical Reviews, 4, 1982, pp. 321-348.

[58] V. Sambamurthy, A. Bharadwaj, and V. Grover, "Shaping Agility through Digital Options: Reconceptualizing the Role of Information Technology in Contemporary Firms", MIS Quarterly, 27(2), 2003, pp. 237-263.

[59] D. Schallmo, C.A. Williams, and L. Boardman, "Digital Transformation of Business Models - Best Practices and Roadmap", International Journal of Innovation Management, 21(08), 2017, 1740014- 1-17.

[60] S. Schneider and P. Spieht, "Business Model Innovation: Towards an Integrated Future Research Agenda", International Journal of Innovation Management, 17(01), 2013, pp. 1-34.

[61] K. Schwab, The Fourth Industrial Revolution, Crown Business, New York, 2017.

[62] I.M. Sebastian, J.W. Ross, C. Beath, M. Mocker, K.G. Moloney, and N.O. Fonstad, "How Big Old Companies Navigate Digital Transformation", MIS Quarterly Executive, 2017, pp. 197-213.

[63] S.M. Shafer, H.J. Smith, and J.C. Linder, "The Power of Business Models", Business Horizons, 48(3), 2005, pp. 199 207.

[64] S.K. Sia, C. Soh, and P. Weill, "How DBS Bank Pursued a Digital Business Strategy", MIS Quarterly Executive, 15(2), 2016, pp. 105-121.

[65] S.C. Srivastava and G. Shainesh, "Bridging the Service Divide Through Digitally Enabled Service Innovations: Evidence from Indian Healthcare Service Providers", MIS Quarterly, 39(1), 2015, pp. 245-267.

[66] S.E. Stief, A.T. Eidhoff, and M. Voeth, "Transform to Succeed: An Empirical Analysis of Digital Transformation in
Firms", International Journal of Social, Behavioral, Educational, Economic, Business and Industrial Engineering, 10(6), 2016, pp. 1833-1842.

[67] D.J. Teece, "Explicating dynamic capabilities: the nature and microfoundations of (sustainable) enterprise performance", Strategic Management Journal, 28(13), 2007, pp. 1319-1350.

[68] D.J. Teece, "Business Models, Business Strategy and Innovation", Long Range Planning, 43(2-3), 2010, pp. 172194.

[69] D.J. Teece and G. Linden, "Business Models, Value Capture, and the Digital Enterprise", Journal of Organization Design, 6(1), 2017, pp. 1-14.

[70] N. Terrenghi, J. Schwarz, and C. Legner, "Towards Design Elements to Represent Business Models for Cyber Physical Systems", Proceedings of the 26th European Conference on Information Systems (ECIS), 2018, pp. 1-16.

[71] D. Veit, E. Clemons, A. Benlian, P. Buxmann, T. Hess, D. Kundisch, J.M. Leimeister, P. Loos, and M. Spann, "Business Models", Business \& Information Systems Engineering, 6(1), 2014, pp. 45-53.

[72] S. Voigt and O. Hinz, "Making Digital Freemium Business Models a Success: Predicting Customers' Lifetime Value via Initial Purchase Information", Business \& Information Systems Engineering, 58(2), 2016, pp. 107-118.

[73] D. Wåge and G.E. Crawford, "Innovation in Digital Business Models", Proceedings of the 28th Innovation Conference (ISPIM), 2017.

[74] B. Wall, H. Jagdev, and J. Browne, "A Review of eBusiness and Digital Business-Applications, Models and Trends", Production Planning \& Control, 18(3), 2007, pp. 239-260.

[75] N. Walton, "The Changing Nature of Value Creation in a Data-Rich World -Platforms, Ecosystems \& Value Networks $\&$ the Impact on Organisational Design \& Configurations", in 13th International Conference. Challenges of Europe: Growth, Competitiveness, Innovation and Wellbeing. 2019.

[76] J. Webster and R.T. Watson, "Analyzing the Past to Prepare for the Future: Writing a Literature Review", MIS Quarterly, 26(2), 2002, pp. xiii-xxiii.

[77] P. Weill and S.L. Woerner, "Optimizing your digital business model", MIT Sloan Management Review, 2013.

[78] P. Weill and S.L. Woerner, "What's Your Digital Business Model?: Six Questions to Help You Build the NextGeneration Enterprise", Harvard Business School Press Books, 2018, p. 1.

[79] B.W. Wirtz, A. Pistoia, S. Ullrich, and V. Göttel, "Business Models: Origin, Development and Future Research Perspectives", Long Range Planning, 49(1), 2016, pp. 36-54.

[80] K. Wnuk and B.T. Murari, "The Impact of Internet of Things on Software Business Models", Proceedings of the 7th International Conference on Software Business (ICSOB), 2016, pp. 94-108. 
[81] Y. Yoo, O. Henfridsson, and K. Lyytinen, "Research Commentary — The New Organizing Logic of Digital Innovation: An Agenda for Information Systems Research", Information Systems Research, 21(4), 2010, pp. 724-735.

[82] Y. Yoo, R.J. Boland, K. Lyytinen, and A. Majchrzak, "Organizing for Innovation in the Digitized World", Organization Science, 23(5), 2012, pp. 1398-1408.

[83] C. Zott and R. Amit, "Business Model Design: An Activity System Perspective", Long Range Planning, 43(2-3), 2010, pp. 216-226.

[84] C. Zott, R. Amit, and L. Massa, "The Business Model: Recent Developments and Future Research", Journal of Management, 37(4), 2011, pp. 1019-1042.

[85] C. Zott and R. Amit, "Business Model Innovation: How to Create Value in a Digital World", GfK Marketing Intelligence Review, 9(1), 2017. 